\title{
Pengembangan Media Scrabble untuk Meningkatkan Procedural Fluency Matematika Siswa SMP
}

\author{
Indri Kusumaningtyas ${ }^{1}$, Tri Nova Hasti Yunianta ${ }^{2}$ \\ ${ }^{1,2}$ Universitas Kristen Satya Wacana, J1. Diponegoro 52-60 Salatiga \\ 202015041@student.uksw.edu
}

\begin{abstract}
This study aimed to develop a mathematics learning media with the subject of integer. The subjects of this study were KANAAN Ungaran Junior High School's class VIIA with 22 students. The type of this study is research and development (R\&D) that used ADDIE develooment model with its stages i.e. Analysis, Design Development, Implementation, Evaluation. The board game media had validation test from material aspects and media aspects. The validity of the material gained an average of $86 \%$ and the media reached $94 \%$ with the category agreed and declared as valid. The practicality of learning media also tested with an average $86 \%$, so its declared as practical. The Wilcoxson test with a significant level of $\alpha=0.05$ yielded a significant close to zero which was less than 0.05 with the post test is higher than pre test.
\end{abstract}

Keywords: $R \& D$, Scrabble Mathematics, Procedural Fluency

\begin{abstract}
Abstrak
Penelitian ini bertujuan untuk mengembangkan suatu media pembelajaran board game mata pelajaran matematika dengan materi Bilangan Bulat. Subyek penelitian ini adalah siswa SMP KANAAN Ungaran kelas VII A dengan jumlah 22 siswa. Jenis penelitian ini adalah penelitian dan pengembangan atau research and development (R\&D) yang menggunakan model pengembangan ADDIE dengan tahapannya yaitu Analysis, Design Development, Implementation, Evaluation. Media pembelajaran board game telah melalui uji validasi dari aspek materi dan aspek media. Kevalidan materi memperoleh rata-rata $86 \%$ dan media mencapai $94 \%$ dengan kategori sangat setuju dan dinyatakan valid. Media pembelajaran juga diuji kepraktisannya dengan ratarata $86 \%$ sehingga media pembelajaran dinyatakan praktis. Uji wilcoxson dengan taraf signifikan $\alpha=0,05$ meghasilkan signifikan mendekati nol yang kurang dari 0,05 dengan rata-rata post test lebih tinggi dari pada pre test.
\end{abstract}

Kata kunci: Pengembangan, Scrabble Matematika, Kelancaran Prosedur

Scrabble merupakan sebuah media yang berbentuk permainan dengan fungsi untuk mengasah otak (S Widiyarto \& Mu’thia, 2017). Menurut Nurjatmika (G Kurnia Putra, 2018) scrabble merupakan jenis permainan yang dapat dimainkan oleh 2 anak atau lebih yang bertujuan untuk mengumpulkan nilai atau poin berdasarkan nilai kata yang tertulis dari tiap huruf yang dapat dilihat pada rangkaian game scrabble. Permainan ini merupakan permainan kata di atas papan berkotak-kotak sejumlah 15 kolom dan 15 baris dengan menggunakan kepingan huruf sejumlah 100 tiles. Pemain menggunakan kepingan huruf untuk membentuk kata baik secara mendatar maupun menurun layaknya bermain tekateki silang (Saadah \& Hidayah, 2013). Scrabble termasuk alat permainan edukatif dengan cara bermain yang sederhana.

Menurut Tedjasaputra (Saadah \& Hidayah, 2013), ciri-ciri alat permainan edukatif yaitu: a) dapat digunakan sesuai dalam berbagai cara sehingga permainan dapat digunakan untuk berbagai macam tujuan, manfaat dan menjadi bermacam-macam bentuk; b) ditujukan terutama untuk anak-anak usia pra sekolah dan berfungsi mengembangkan berbagai aspek perkembangan kecerdasan serta motorik anak; c) segi keamanan sangat diperhatikan, baik dari bentuk maupun penggunaan bahan; d) 
Pengembangan Media Scrabble untuk Meningkatkan Procedural Fluency Matematika Siswa SMP, Indri Kusumaningtyas, Tri Nova Hasti Yunianta

membuat anak terlibat aktif, bersifat konstruktif atau membangun. Hal ini dapat disimpulkan, bahwa alat permainan edukatif sangat membantu siswa lebih tertarik untuk belajar dan dalam memahami konsep.

Menurut Depdiknas (Kesumawati, 2008) mengungkapkan bahwa, pemahaman konsep merupakan salah satu kecakapan atau kemahiran matematika yang diharapkan dapat tercapai dalam belajar matematika yaitu dengan menunjukkan pemahaman konsep matematika yang dipelajarinya, menjelaskan keterkaitan antar konsep dan mengaplikasikan konsep atau algoritma secara luwes, akurat, efisien, dan tepat dalam pemecahan masalah.

Dengan adanya pemahaman, siswa dapat mengerjakan soal matematika dengan lancar. Klipatrick, Swafford, \& Findell, 2001: 121 (Larasati, 2017) mengungkapkan bahwa kelancaran prosedural dapat digambarkan sebagai ketrampilan serta kemampuan siswa dalam melaksanakan pengetahuan mengenai prosedur, serta kemampuan dalam membangun fleksibilitas, keakurat serta efisien dalam menyelesaikan suatu masalah. Tanpa adanya kelancaran prosedural, siswa mengalami kesulitan dalam memahami tentang matematika atau memecahkan masalah matematika.

Melalui hasil observasi yang dilakukan terhadap siswa SMP kelas VII di Kota Ungaran (Kabupaten Semarang) yang sudah mendapatkan materi bilangan, ditemukan siswa cenderung kesulitan dalam mengerjakan soal dikarenakan kelancaran prosedural yang kurang tepat. Keterampilan dalam kelancaran prosedural ini memang perlu diasah melalui latihan. Pada Gambar 1 dapat diketahui bahwa pada butir soal nomor 1 dalam penyelesaian masalah siswa tidak dapat menyelesaiakan perhitungan -4 - 3 dan pada nomor 3 siswa secara prosedur penyelesaian soal tidak benar dikarenakan tanda bagi pada penyelesaian tahap pertama tidak ditulis, namun ditulis dipenyelesaian soal tahap 2 .

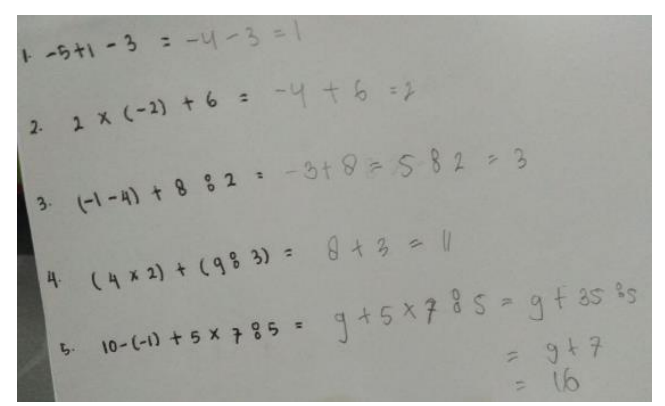

Gambar 1. Hasil Jawaban Siswa dalam Menyelesaikan Soal Bilangan.

Hasil pekerjaan siswa menunjukkan bahwa kurangnya keterampilan kelancaran procedural dalam pengurangan bilangan bulat negatif dan dalam proses pembagian sehingga siswa dalam mengerjakan soal membutuhkan waktu yang lama. Hal ini dapat disimpulkan bahwa perlu bantuan dalam melatih kelancaran prosedural siswa.

Bantuan di sini yang menjadi fokus penyelesaian masalah di atas adalah memberikan media pembelajaran. Media pembelajaran menurut Dictonary (1960) dapat diartikan sebagai sesuatu yang mengantarkan pesan pembelajaran antara pemberi pesan kepada penerima pesan. Assocition for Educational Comunications and Technology (AECT, 1997) mendefinisikan media sebagai segala bentuk yang digunakan untuk menyalurkan informasi. Berdasarkan masalah di atas, dipandang perlu 
pengembangan media pembelajaran berupa alat peraga permainan scrabble matematika. Melalui pengembangan ini diharapkan keterampilan kelancaran prosedural siswa dapat meningkat pada materi bilangan bulat.

Scrabble matematika dibuat dari papan berukuran $55 \times 55 \mathrm{~cm}$, dengan bingkai setiap sisinya $5 \mathrm{~cm}$. Kotak-kotak dalam papan sejumlah 15 kolom dan 15 baris dengan kepingan sejumlah 100 tiles yang terdiri dari operasi hitung dan angka. Permainan scrabble matematika ini memiliki desain yang hampir sama seperti permainan scrabble pada umumnya.

Menurut hasil penelitian D Aries Santi (2014), media scrabble huruf hiragana berpengaruh postif karena dapat meningkatkan hasil belajar pada mata pelajaran Bahasa Jepang siswa dengan lebih baik. L Hartati (2015) mengungkapkan bahwa hasil belajar matematika adalah hasil akhir yang dimiliki oleh siswa berupa kemampuan-kemampuan dalam menguasai, memahami konsep dalam pelajaran matematika sebagai ilmu tentang logika mengenai bentuk, sususan, besaran dan konsepkonsep yang saling berhubungan satu sama lainnya yang menggunakan istilah serta didefinisikan dengan cermat, jelas dan akurat untuk membantu manusia dalam memahami dan menguasai permasalahan sosial, ekonomi, dan alam setelah melalui proses belajar. Menurut Yualdi \& Ganda (2013), permainan scrabble dapat meningkatkan gairah belajar siswa dalam membaca, karena penggunaan bahan yang menarik dapat menyeimbangkan otak kanan dan otak kiri anak sehingga permainan scrabble ini efektif digunakan untuk meningkatkan kemampuan membaca permulaan bagi anak kesulitan membaca.

Penelitian pengembangan media scrabble matematika pada materi Bilangan bulat diharapkan dapat membantu siswa untuk meningkatkan keterampilan kelancaran prosedural. Manfaat tambahannya juga diharapkan membantu guru matematika dalam menyediakan materi Bilangan Bulat dengan tampilan yang lebih inovatif dan menarik.

\section{METODE PENELITIAN}

Penelitian ini disusun menggunakan Research and Development (R\&D). Penelitian pengembangan adalah metode penelitian yang digunakan untuk menghasilkan produk tertentu dan menguji keaktifan produk tersebut (Sugiyono, 2014:297). Produk yang dihasilkan dalam penelitian ini berupa media pembelajaran matematika pada materi Bilangan Bulat untuk siswa SMP kelas VII Tahun ajaran baru 2018/2019. Penelitian ini menggunakan model pengembangan untuk media pembelajaran yang mengacu pada jenis pengembangan model ADDIE (Analysis, Design, Development, Implementation, Evaluation). Kelima langkah dalam model ADDIE perlu dilakukan secara sistemik dan sistematik.

Langkah pertama adalah tahap analyze, tahap ini menganalisis kebutuhan siswa untuk menentukan masalah, solusi yang tepat, dan menentukan kompetensi siswa. Kedua, tahap design yaitu mendesain material dan menentukan kompetensi khusus, metode, bahan ajar, dan strategi pembeajaran. Langkah ketiga adalah development dilakukan dengan produksi media dan bahan ajar 
Pengembangan Media Scrabble untuk Meningkatkan Procedural Fluency Matematika Siswa SMP, Indri Kusumaningtyas, Tri Nova Hasti Yunianta

yang digunakan dalam pembelajaran. Selanjutnya langkah keempat adalah implementation atau pengimplementasian media scrabble dengan mempraktikkan secara langsung. Tahap akhir yaitu tahap evaluasi yang merupakan tahap untuk menyempurnakan media pembelajaran setelah diuji-cobakan.

Subyek penelitian pengembangan ini adalah siswa kelas VII SMP Kanaan Ungaran Tahun Ajaran 2018/2019. Dengan kebijakan pihak dari sekolah, peneliti diijinkan untuk melakukan penelitian kelas VII A sebanyak 22 siswa, yang terdiri dari 11 perempuan dan 11 laki-laki.

Teknik pengumpulan data yang digunakan berupa angket validasi instrumen berupa ahli materi, ahli media, angket kepraktisan dan angket keefektifan untuk mengukur keterampilan kelancaran prosedural siswa dengan menggunakan media pembelajaran srcabble matematika.

\section{HASIL PENELITIAN DAN PEMBAHASAN}

Penelitian ini menggunakan pendekatan penelitian dan pengembangan R\&D (Research and Development), dengan menggunakan model ADDIE (Analyze, Design, Develolopment, Implementation, and Evaluation). Tahap-tahap tersebut dilakukan untuk menciptakan media pembelajaran matematika yang valid, praktis, dan efektif untuk digunakan sebagai media latihan soal materi Bilangan Bulat pada jenjang SMP. Berikut adalah uraian dari kelima tahap tersebut.

\section{Analyze (Analisis)}

Analisis ini menggunakan jenis media board game. Penelitian ini melibatkan siswa kelas VII SMP Kanaan Ungaran sebagai subjek penelitian. Berdasarkan hasil analisis, siswa kelas VII berjumlah 22 siswa yang terdiri dari 11 siswa laki-laki dan 11 siswa perempuan, dimana hanya 20 siswa yang menggunakan scrabble, 2 siswa tidak menggunakan melainkan menulis skor permainan siswa lainnya.

Media scrabble yang dikembangkan peneliti adalah media yang akan digunakan sebagai sarana latihan soal Bilang bulat. Materi ini mencakup indikator yaitu Mmenyelesaikan soal penjumlahan, pengurangan, perkalian dan pembagian bentuk bilangan bulat. Oleh karena itu, dalam mengembangkan media scrabble matematika perlu memperhatikan cakupan materi tersebut.

\section{Design (Desain)}

Tahap desain merupakan inti dari langkah analisis, yaitu mempelajari masalah dan menemukan alternatif solusi melalui langkah analsis.

Langkah-langkah desain adalah sebagai berikut:

\section{Menentukan Kompetensi Dasar}

Penelitian ini dilaksanakan di SMP Kanaan Ungaran yang telah menggunakan Kurikulum 2013 dalam proses pembelajarannya. Pengembangan media scrabble matematika disesuaikan dengan hasil analisis dan standar pembelajaran yang telah ditetapkan Kurikulum 2013. Materi bilangan bulat memiliki kompetensi dasar yaitu: (4.2) Menyelesaikan masalah yang berkaitan dengan operasi hitung bilangan bulat dan pecahan. Di mana siswa dapat membedakan operasi hitung pada materi Bilangan bulat. 


\section{Menentukan Tujuan Belajar}

Pengembangan media scrabble matematika pada materi bilangan bulat disesuaikan dengan tujuan belajar Kurikulum 2013. Berdasarkan kompetensi di atas, terdapat pengalaman yang harus dimilik siswa yaitu: (1) siswa mampu menjelaskan berbagai sifat operasi hitung yang melibatkan bilangan bulat; (2) siswa mampu menentukan hasil operasi hitung bilangan bulat dengan memanfaatkan berbagai sifat operasi. Media scrabble ini akan didesain agar siswa mampu memperoleh tujuan diatas.

\section{Development (Pengembangan)}

\section{Memilih Teknologi dan Media}

Pengembangan scrabble matematika dalam penelitian ini adalah papan permainan yang terbuat dari kertas karton yang tebal dengan ukuran $55 \mathrm{~cm} \times 55 \mathrm{~cm}$, dengan alat bantu tile sebanyak 150. Media ini nantinya digunakan untuk pembelajaran di sekolah maupun di luar sekolah.

\section{Memilih Materi Pembelajaran}

Materi yang diterapkan pada scrabble matematika adalah Bilangan Bulat. Berdasarkan dari tahap analisis, kelas VII SMP Kanaan Ungaran telah menggunakan buku Paket Matematika kurikulum 2013 revisi 2017.

\section{Pembuatan Media Scrabble Matematika}

\section{Papan Scrabble Matematika}

Papan merupakan komponen paling penting pada media scrabble. Fungsi dari papan ini sebagai tempat jalannya permainan. Tampilan pada papan terdiri dari 225 kotak, masing-masing kotak dalam papan diberi warna yang berbeda. Tujuannya untuk menarik siswa mendapatkan poin atau tile. Pembuatan papan ini dilakukan dengan mendesain menggunakan aplikasi CorelDraw X7 dan dicetak untuk ditempelkan dikertas karton yang tebal (yellowboard) dengan ukuran $55 \mathrm{~cm} \times 55 \mathrm{~cm}$. Pemilihan yellowboard dimaksud agar media ringan saat dibawa dan mudah dalam pemeliharaannya. Media ini dibagi menjadi 4 lipatan agar tidak terlalu besar, dengan masing-masing ukuran 27,5 cm. Kemudian dilapisi dengan stiker untuk menarik atau memberi gambar pada media scrabble. Hasil desain setelah mendapatkan tiga kali revisi terlihat pada Gambar 2.

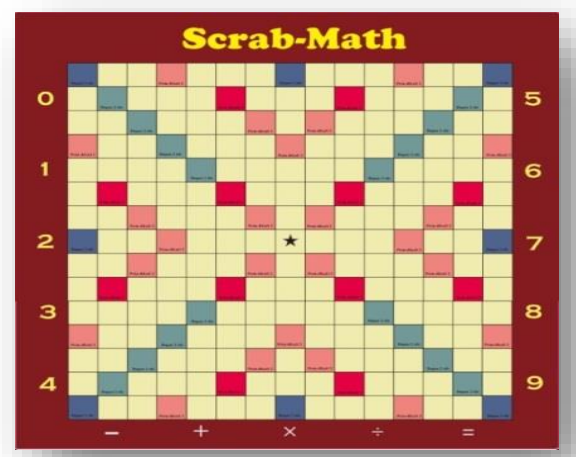

Gambar 2. Tampilan Papan Scrabble Matematika setelah tiga kali revisi 
Pengembangan Media Scrabble untuk Meningkatkan Procedural Fluency Matematika Siswa SMP, Indri Kusumaningtyas, Tri Nova Hasti Yunianta

Hasil revisi terakhir pada papan scrabble memilih warna merah tua dengan tulisan berwarna kuning dan operasi bilangan bulat berwarna putih. Warna tersebut dipilih karena warna dirasa cukup semangat dan menarik siswa untuk belajar.

Tile

Tile dalam media scrabble ini memiliki peran penting. Tujuan pembuatan tile untuk memainkan angka dan operasi materi bilangan bulat. Setiap tile diberi poin yang berbeda-beda. Guna poin untuk menentukan pemenang dalam bermain sekaligus belajar. Tile ini didesain menggunakan aplikasi CorelDraw X7 dengan kotak kecil berukuran $3 \mathrm{~cm}$. Pewarnaan tile angka dan tile operasi tidak dibedakan. Agar memudahkan siswa dalam bermain sekaligus belajar.

Tile ini terbuat dari kayu yang dipotong-potong kecil sesuai ukuran pada CorelDraw X7 sebanyak 150 tile. Terdiri dari angka dan operasi bilangan bulat. Pembuatan tile tidak jauh beda dengan pembuatan papan scrab-math. Dimana desain pada tile dicetak menjadi stiker dan ditempel pada kayu yang sudah dipotong kecil. Tile dapat dilihat pada Gambar 3.

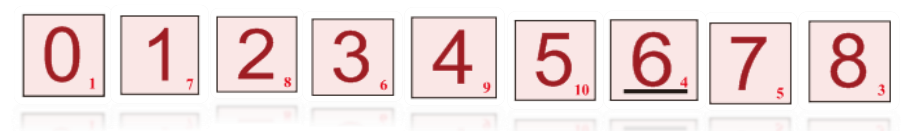

Gambar 3. Tampilan tile

\section{Buku Poin dan Petunjuk Scrabble Matematika}

Pembuatan desain pada buku poin dan petunjuk scrabble matematika ini menggunakan Microsoft Publiser 2010. Kegunaan buku untuk menulis hasil poin yang dimainkan siswa dan setiap siswa tahu berapa poin yang didapatkan. Petunjuk scrab-math membantu atau memudahkan siswa dalam bermain. Hasil desain buku poin dan petunjuknya dapat dilihat pada Gambar 4.
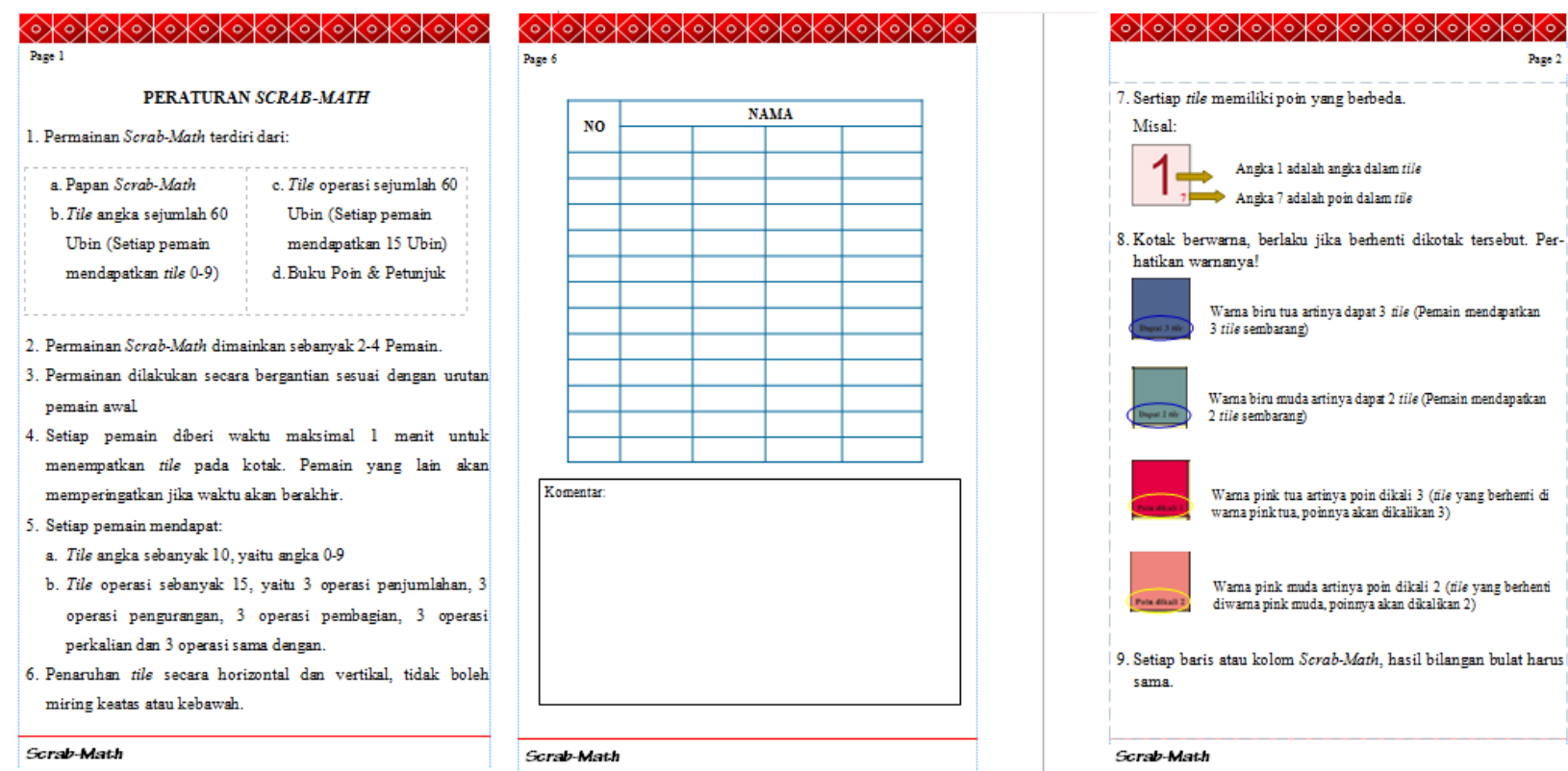

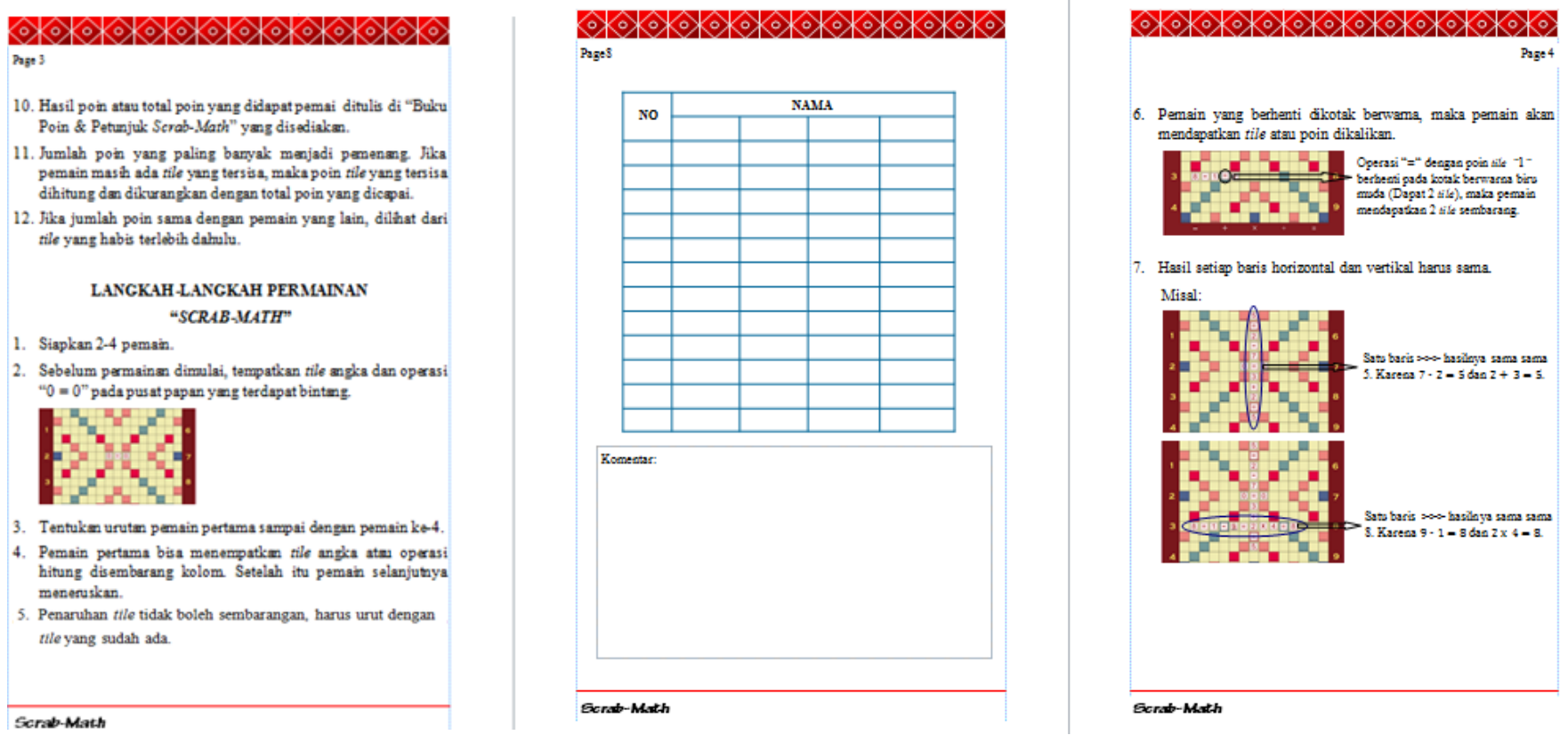

Gambar 4. Tampilan Buku poin dan buku petunjuk

Berdasarkan gambar diatas, guna buku ini untuk mengetahui langkah dan peraturan cara bermain media scrab-math. Jika pemain sudah paham dengan aturan dan langkah, dipersilahkan untuk menentukan pemain pertama hingga pemain selanjutnya. Pemain pertama akan menaruhkan tile pada kolom setelah angka " $0=0$ ", pemain selanjutnya bisa melanjutkan permainannya. Pemain yang diberhenti dikolom warna warni, tandanya pemain akan mendapatkan tile atau poin. Poin yang didapat ditulis di buku poin. Jika poin sudah terkumpul dan sudah dihitung, poin yang paling banyak adalah pemenangnya.

\section{Pengemasan Media Scrabble Matematika}

Media ini juga memperhatikan aspek kepraktisan dalam penyimpanan, maka didesain pengemasan dalam bentuk sebuah kardus. Desain pada kardus menggunakan CorelDraw X7. Ukuran kardus disesuaikan dengan banyaknya alat-alat pada scrab-math. Fungsi kardus ini untuk wadah scrabble. Pengemasan ini menggunakan bahan yang awet yaitu kertas karton yang tebal (yellowboard). Bentuk pengemasan media dapat dilihat pada Gambar 5.

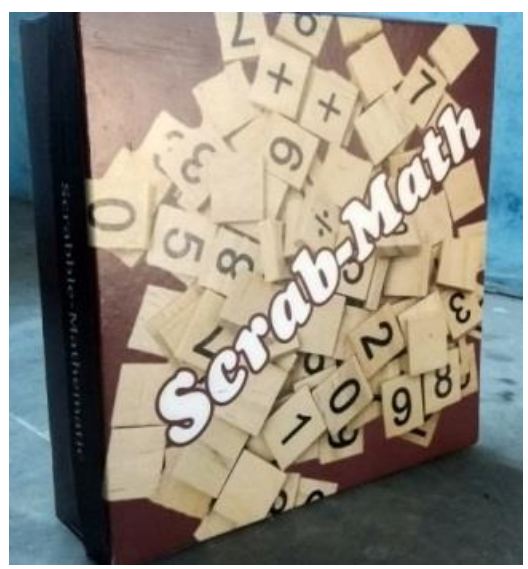

Gambar 5. Pengemasan Media Scrabble Matematika 
Pengembangan Media Scrabble untuk Meningkatkan Procedural Fluency Matematika Siswa SMP, Indri Kusumaningtyas, Tri Nova Hasti Yunianta

\section{Soal Evaluasi}

Soal Evaluasi diambil dari Buku Paket Matematika SMP/MTs Kelas VII Semester I Revisi 2017 yang dibuat oleh As'ari dkk.

\section{Implementation (Implementasi)}

\section{Validasi Ahli}

Media pembelajaran scrabble matematika divalidasi oleh validasi ahli atau validator. Proses validasi menggunakan instrumen yang telah disiapkan dan telah disetujui oleh dosen pembimbing. Instrumen validasi memiliki dua aspek yaitu aspek media dan aspek materi. Lembar validasi media terdiri dari 17 indikator dan 8 indikator untuk aspek materi. Validasi dilaksanakan dengan tujuan untuk memperoleh kritik dan saran dari validator yang memang ahli dibidangnya dalam pengembangan board game, dan sebagai bukti bahwa media dan materi layak digunakan dalam penelitian. Daftar validator ahli media dan materi terdapat pada Tabel 1.

\section{Tabel 1.}

\section{Daftar Validator}

\begin{tabular}{|c|l|}
\hline No & \multicolumn{1}{|c|}{ Validator } \\
\hline 1. & Dosen Pendidikan Matematika Universitas Kristen Satya Wacana \\
\hline 2. & Dosen Sains dan Matematika Universitas Kristen Satya Wacana \\
\hline 3. & Guru Matematika SMP Kanaan Ungaran \\
\hline
\end{tabular}

Kritik dan saran yang diberikan validator menjadi acuan dalam perbaikan scrabble matematika. Saran dan kritik yang diberikan oleh validator diuraikan pada Tabel 2.

Tabel 2.

Daftar Kritik dan Saran

\begin{tabular}{|l|l|}
\hline Validator & \multicolumn{1}{c|}{ Kritik dan Saran } \\
\hline Validator 1 & $\begin{array}{l}\text { 1. Indeks poin perlu dijelaskan } \\
\text { 2. Tambahkan identitas nama pembuat/instansi } \\
\text { 3. Bahan bisa dicetak dengan Akrilik }\end{array}$ \\
\hline Validator 2 & $\begin{array}{l}\text { 1. Perlu diperhatikan untuk soal pre-test dan posttest } \\
\text { pembagian }\end{array}$ \\
& $\begin{array}{l}\text { 2. Kunci jawaban perlu diperhatikan } \\
\text { 3. Soal bisa dikaitkan dengan sifat-sifat bilangan bulat. }\end{array}$ \\
\hline Validator 3 & $\begin{array}{l}\text { 1. Media sudah baik. } \\
\text { 2. Media yang digunakan menarik dan bisa digunakan untuk } \\
\text { belajar sekaligus bermain. }\end{array}$ \\
\hline
\end{tabular}

\section{Revisi Produk}

Revisi Produk ini disesuaikan dengan kritik dan saran yang diberikan validator. Kritik, Saran dan Tindak lanjut diuraikan pada Tabel 3. 
Tabel 3.

Kritik, Saran dan Tindak Lanjut

\begin{tabular}{|c|c|}
\hline Kritik dan Saran & Tindak Lanjut \\
\hline $\begin{array}{l}\text { 1. Warna pada media kurang menarik } \\
\text { 2. Operasi Bilangan Bulat disesuaikan dengan } \\
\text { font Matematika }\end{array}$ & $\begin{array}{l}\text { Mengganti warna dan } \\
\text { menyesuaikan font operasi } \\
\text { Bilangan Bulat. }\end{array}$ \\
\hline $\begin{array}{l}\text { 1. Indeks poin perlu dijelaskan } \\
\text { 2. Tambahkan identitas nama pembuat/instansi } \\
\text { 3. Bahan bisa dicetak dengan Akrilik }\end{array}$ & $\begin{array}{l}\text { 1. Memperjelas indek poin. } \\
\text { 2. Memberi identitas pada } \\
\text { media. }\end{array}$ \\
\hline $\begin{array}{l}\text { 1. Perlu diperhatikan untuk soal pembagian } \\
\text { 2. Kunci jawaban perlu diperhatikan } \\
\text { 3. Soal bisa dikaitkan dengan sifat-sifat bilangan } \\
\text { bulat. }\end{array}$ & $\begin{array}{l}\text { Pembetulan soal dan kunci } \\
\text { jawab }\end{array}$ \\
\hline
\end{tabular}

\section{Evaluation (Evaluasi)}

\section{Analisis data validasi}

Analisis data dilakukan berdasarkan hasil penilaian validator meliputi aspek media dan aspek materi. Berikut penjelasan masing-masing aspek.

\section{Aspek Media}

Aspek media scrabble matematika terdiri dari 16 indikator, media ini diajukan kepada 2 validator berupa instrumen angket yang terdiri dari aspek tampilan, aspek aturan permainan, aspek pembuatan, aspek penggunaan dan pemeliharaan, aspek pengemasan dan aspek kebermanfaatan. Paparan hasil validasi dari validator ahli media dapat dilihat pada Tabel 4.

\section{Tabel 4.}

\section{Validasi Ahli Media}

\begin{tabular}{|c|c|c|c|}
\hline Aspek Penilaian & & Persentase & Kategori \\
\hline Tampilan Media & & $95 \%$ & Sangat Setuju \\
\hline Aturan Permainan & & $87 \%$ & Sangat Setuju \\
\hline Pembuatan & & $100 \%$ & Sangat Setuju \\
\hline $\begin{array}{l}\text { Penggunaan } \\
\text { Pemeliharaan }\end{array}$ & dan & $92 \%$ & Sangat Setuju \\
\hline Pengemasan & & $100 \%$ & Sangat Setuju \\
\hline Kebermanfaatan & & $92 \%$ & Sangat Setuju \\
\hline Rata-rata & & $94 \%$ & Sangat Setuju \\
\hline
\end{tabular}

Berdasarkan hasil penilaian dari validator media, tampak bahwa keenam aspek penilaian media masuk dalam kategori sangat setuju dengan presentase $94 \%$ sehingga media ini dinyatakan valid.

\section{Aspek Materi}

Aspek materi scrabble matematika terdiri dari 9 indikator, media ini diajukan kepada validator berupa instrumen angket yang terdiri dari aspek materi dan aspek kontruksi. Paparan hasil validasi dari validator materi dapat dilihat pada Tabel 5 . 
Pengembangan Media Scrabble untuk Meningkatkan Procedural Fluency Matematika Siswa SMP, Indri Kusumaningtyas, Tri Nova Hasti Yunianta

\section{Tabel 5.}

Hasil Validasi Validator Materi

\begin{tabular}{lcc}
\hline \multicolumn{1}{c}{ Aspek Penilaian } & Persentase & Kategori \\
\hline Aspek Materi & $79 \%$ & Setuju \\
Aspek Konstruksi & $100 \%$ & Sangat Setuju \\
Rata-rata & $86 \%$ & Sangat Setuju \\
\hline
\end{tabular}

Berdasarkan Tabel 5, terlihat bahwa rata-rata dari bagian aspek materi dan aspek konstruksi sebesar $86 \%$ yang berarti bahwa soal-soal yang ada scrabble matematika telah beragam dan mencakup indikator dalam materi Bilangan bulat. Selain itu, tingkat kesulitan pada soal juga sesuai dengan kemampuan yang dimiliki siswa sehingga materi dalam media ini dinyatakan valid.

Hasil validator dari Tabel 4. dan Tabel 5. dapat disimpulkan bahwa media Scrabble matematika valid digunakan untuk sarana belajar dan bermain. Hasil tersebut serupa dengan hasil penelitian yang dilakukan oleh (Riawan A \& Wanarti R, 2018), (Hardianti F, 2019), (Mardika N, 2017), (Hikmawanti A \& Sukanti S, 2016), (Ristanto, Sukardi \& Susilaningsih, 2012), (Priyanto A, 2018). Hasil penelitian tersebut, menyimpulkan bahwa media yang diciptakan berdampak positif dan meningkatkan minat hasil belajar siswa, dan dapat digunakan untuk mata pelajaran yang lain.

\section{Analisis data kepraktisan}

Kepraktisan media board game matematika dinilai berdasarkan hasil penilaian validator media dapat dilihat pada Tabel 6 .

Tabel 6.

Hasil Penliaian Kepraktisan

\begin{tabular}{lcl}
\hline \multicolumn{1}{c}{ Aspek Penilaian } & Persentase & Kategori \\
\hline Aspek Pembuatan & $100 \%$ & Sangat Setuju \\
Aspek Penggunaan & $89 \%$ & Sangat Setuju \\
Aspek Pemilihan Bahan & $94 \%$ & Sangat Setuju \\
Rata-rata & $86 \%$ & Sangat Setuju \\
\hline
\end{tabular}

Berdasarkan hasil penilaian dari validator diperoleh rata-rata $86 \%$ sehingga media dinyatakan praktis.

\section{Analisis Data Keefektifan Media}

\section{Data Hasil Tes Keterampilan Kelancaran Prosedural}

Pada saat penelitian melakukan uji coba media scrabble matematika ke pada subjek, peneliti melakukan pretest dan posttest untuk mengetahui pemahaman siswa tentang scrab-math. Pretest dan posttest ini disusun dengan tingkat kesulitan soal agar dapat mengetahui tingkat kemajuan 
pemahaman siswa. Berdasarkan data hasil belajar pre-test dan post-test siswa yang telah terkumpul, kemudian direkapitulasi hasilnya dengan rumus Likert.

$$
\mu=\frac{\sum x}{N}
$$

Keterangan:

$$
\begin{array}{ll}
\mu & : \text { Nilai rata-rata } \\
\Sigma x & : \text { Jumlah Skor } \\
N & : \text { Jumlah pertanyaan pada setiap kategori }
\end{array}
$$

Dengan hasil rata-rata pre-test (72) dan post-test (77). Dapat dilihat bahwa siswa kelas VII SMP Kanaan Ungaran mengalami peningkatan yang cukup signifikan setelah menggunakan media Board Game. Untuk memenuhi jenis uji, dilakukan uji normalitas. Hasil uji Normalitas dapat dilihat pada Tabel 7.

Tabel 7.

Hasil Uji Normalitas

\begin{tabular}{lcccccc}
\hline & \multicolumn{3}{c}{ Kolmogorov-Smirnov $^{\mathrm{a}}$} & \multicolumn{3}{c}{ Shapiro-Wilk } \\
& Statistic & df & Sig. & Statistic & df & Sig. \\
\hline Pretest & .282 & 22 & .000 & .878 & 22 & .011 \\
Postest & .297 & 22 & .000 & .849 & 22 & .003 \\
a. Lilliefors Significance Correction & & & & \\
\hline
\end{tabular}

Uji normalitas yang digunakan adalah Shapiro-Wilk dikarenakan jumlah sampel pada penelitian sebanyak 22 (kurang dari 30). Terlihat bahwa hasil dari uji normalitas Shapiro-Wilk menunjukan nilai signifikansi untuk pretest 0.011 dan posttest 0.003 dimana hasil pretest tertera 0.011 yang berarti lebih dari 0.05 , sedangkan posttest tertera 0.003 yang berarti kurang dari 0.05 . Oleh karena itu dapat disimpulkan bahwa data posttest berasal dari populasi yang berdistribusi normal sehingga uji beda rerata yang digunakan adalah uji non parametic dengan uji wilcoxson. Hasil uji ini dapat dilihat pada Tabel 8.

\section{Tabel 8.}

Uji Wilcoxson

Postest - Pretest

\begin{tabular}{lr}
$Z$ & $-2.244^{\mathrm{a}}$ \\
\hline Asymp. Sig. (2-tailed) & .025 \\
a. Based on negative ranks. & \\
b. Wilcoxon Signed Ranks Test & \\
\hline
\end{tabular}


Pengembangan Media Scrabble untuk Meningkatkan Procedural Fluency Matematika Siswa SMP, Indri Kusumaningtyas, Tri Nova Hasti Yunianta

Hasil uji wilcoxson dengan signifikan 0,05 pada tabel 16 tertulis nilai signifikan 0.025 yang artinya nilai signifikan lebih dari 0.05 dengan rata-rata nilai posttest (77) lebih tinggi daripada ratarata pretest (72) maka dapat disimpulkan bahwa media efektif untuk digunakan sebagai sarana latihan soal Materi Bilangan Bulat pada jenjang SMP.

\section{Data Hasil Pendapat Siswa}

Setelah dilakukannya pretest dan postest, siswa memberikan pendapat/respon tentang media yang telah dimainkan. Hasil Rekapitulasi Pendata Siswa dapat dilihat pada Tabel 9.

Tabel 9.

Hasil Rekapitulasi Pendapat Siswa

\begin{tabular}{lccc}
\hline \multirow{2}{*}{\multicolumn{1}{c}{ Indikator }} & \multicolumn{2}{c}{ Keterangan (\%) } & \multirow{2}{*}{ Kesimpulan } \\
\cline { 2 - 3 } & Setuju & Tidak Setuju & \\
\hline Aturan bermain & $77 \%$ & $23 \%$ & Setuju \\
Media mudah digunakan & $59 \%$ & $41 \%$ & Setuju \\
Peluang Keberhasilan & $72 \%$ & $27 \%$ & Setuju \\
Mengajarkan untuk belajar & $100 \%$ & - & Setuju \\
Daya tarik Media & $82 \%$ & $18 \%$ & Setuju \\
Menumbuhkan mint belajar & $77 \%$ & $23 \%$ & Setuju \\
Permainan menantang & $91 \%$ & $9 \%$ & Setuju \\
Digunakan terus-menerus & $55 \%$ & $45 \%$ & Setuju \\
Bermain sambil belajar & 100 & - & Setuju \\
Media bermanfaat & $64 \%$ & $36 \%$ & Setuju \\
\multicolumn{1}{c}{$\quad$ Rata-rata } & $78 \%$ & $22 \%$ & \\
\hline
\end{tabular}

Berdasarkan hasil pendapat siswa/respons siswa terlihat bahwa rata-rata yang diperoleh dari keseluruhan siswa adalah 78\% dinyatakan setuju untuk menggunakan media pembelajaran scrabble matematika. Pernyatakan tidak setuju untuk media ini hanya $22 \%$. Dapat disimpulkan bahwa media yang dikembangkan peneliti valid, praktis, dan efektif sebagai media pembelajaran.

\section{PEMBAHASAN}

Penelitian ini mengembangkan media scrabble matematika pada materi bilangan bulat dengan dibuktikan melalui proses pembuatan dilakukan sesuai dengan model pengembangan ADDIE yang meliputi Analyze, Design, Development, Implementation, dan Evaluation. Media ini terdiri dari papan scrabble, tile, dan buku petunjuk \& buku poin. Dari penelitian yang sudah dilakukan oleh peneliti, dapat dilihat bahwa Penilaian lembar validasi media dibagi menjadi dua aspek yaitu aspek media dan aspek materi. Berdasarkan hasil validasi diperoleh kritik dan saran yang akan dijadikan acuan dalam perbaikan media. Proses hasil validasi terhadap aspek media dapat disimpulkan bahwa media pembelajaran scrabble matematika dinyatakan valid dengan presentase rata-rata $94 \%$, sedangkan dari aspek materi dapat dinyatakan valid dengan memperoleh presentase rata-rata $86 \%$.

Penilaian kepraktisan juga diperlukan berdasarkan instrumen lembar kepraktisan. Hasil kepraktisan media dapat dinyatakan praktis dengan memperoleh presentase rata-rata $86 \%$. Media 
scrabble matematika praktis digunakan karena mudah digunakan serta dapat digunakan kapan dan dimana saja. Oleh karena itu dapat disimpulkan media ini praktis digunakan dalam pembelajaran matematika. Penilaian keefektifan juga ditentukan berdasarkan data hasil pretest dan posttest yang telah terkumpul kemudian dihitung peningkatannya menggunakan uji wilcoxson dengan taraf signifikansi $\alpha=0.05$ menghasilkan signifikansi mendekati nol yang kurang dari 0.05 dengan rata-rata postest lebih tinggi dari pada pretest.

Berdasarkan hasil analisis lembar pendapat siswa menunjukkan bahwa media scrab-math mudah dimengerti, dipelajari dan dimainkan dimana dan kapanpun. Media ini juga menarik, menantang dan menyenangkan siswa untuk dimainkan. Berdasarkan pendapat dari 22 siswa (satu kelas) sebagai subjek penelitian dapat disimpulkan bahwa media scrabble matematika mendapat respons positif dari siswa untuk digunakan.

Berdasarkan penelitian yang dilakukan Yualdi dkk (2013) yang berjudul "Efektifitas Permainan Scrabble dalam Meningkatkan Kemampuan membaca Permulaan Bagi Anak Kesulitan Membaca”, membahas seorang anak yang kesulitan dalam membaca dikelas III SD Negeri 20 Binuang Pauh Padang yang beridentitas X berumur 10 Tahun. Anak dapat membaca item pada deskritor dengan skor pada pertemuan pertama 30\% hingga pertemuan kelima 10\% dan mengalami penurunan. Pada pertemuan pertama hingga pertemuan ke-12 skor yang diperoleh anak $100 \%$. Dimana anak tersebut mengalami peningkatan dalam membaca.

Penelitian yang kedua oleh Desiana (2014) yang mengembangkan media scrabble dengan materi Bahasa Jawa kelas VI SD. Penelitian ini dilakukan dengan jumlah subjek sebanyak 30 siswa kelas VI SD Negeri Keputran A Yogyakarta. Subyek terdiri dari 20 siswa perempuan dan 10 siswa laki-laki. Subyek penelitian diminta untuk melakukan scrabble hanacara kemudian diberi lembar pretest, postest dan lembar pendapat siswa untuk memberikan penilaian terhadap media pembelajaran yang telah digunakan. Hasil pretest $(50,58)$ dan postest $(76,25)$. Hal tersebut menunjukkan peningkatan rata-rata skor sebesar 25,66 sehingga dapat disimpulkan media pembelajaran aksara Jawa efektif dalam meningkatkan hasil belajar siswa, sedangkan untuk lembar pendapat siswa memperoleh rata-rata 4.03 dengan kategori baik.

\section{KESIMPULAN}

Produk yang dihasilkan dalam penelitian adalah media scrabble matematika pada materi Bilangan bulat untuk siswa kelas VII SMP Kanaan Ungaran. Hasil penelitian ini di validasi oleh validator ahli media dan ahli materi dan skor yang diperoleh untuk validasi media dari dua validator aspek penilaian dengan memperoleh presentase tampilan 95\%, aturan dalam permainan $87 \%$, bahan dalam pembuatan media $100 \%$, penggunaan dan pemeliharaan media $92 \%$, pengemasan media $100 \%$ dan manfaat dalam media $92 \%$. Hasil penilaian dari validator memperoleh rata-rata $94 \%$ sehingga termasuk kategori sangat setuju. Sementara hasil penilaian ahli materi diperoleh presentase untuk aspek materi $79 \%$ dan aspek kontruksi $100 \%$ dengan rata-rata presentase $86 \%$ termasuk kategori 
Pengembangan Media Scrabble untuk Meningkatkan Procedural Fluency Matematika Siswa SMP, Indri Kusumaningtyas, Tri Nova Hasti Yunianta

sangat setuju. Analisis kepraktisan juga diperlukan, hal ini media dapat dinyatakan praktis dengan memperoleh presentase dari dua validator yaitu $86 \%$.

Media ini diuji cobakan dengan menghitung hasil pretest dan postest dengan uji wilcoxson dengan taraf signifikansi $\alpha=0.05$ menghasilkan signifikansi mendekati nol yang kurang dari 0.05 dengan rata-rata postest lebih tinggi dari pada pretest. Berdasarkan hasil ketiga uji tersebut, maka disimpulkan bahwa media scrabble matematika dapat meningkatkan procedural fluency matematika siswa. Oleh karena itu media dapat digunakan sebagai sarana latihan soal untuk materi Bilangan Bulat pada jenjang SMP.

Berdasarkan hasil penelitian yang telah dilakukan, diharapkan media scrabble matematika dapat digunakan untuk materi lain, konten materi Bilangan bulat dapat diperdalam lagi, media ini memungkinkan untuk dikembangkan pada mata pelajaran yang lain.

\section{DAFTAR PUSTAKA}

Aries Santi, D. W. I. E. (2014). Pengembangan Media Scrabble Huruf Hiragana Untuk Meningkatkan Hasil Belajar Pada Mata Pelajaran Bahasa Jepang Untuk Siswa Kelas X Di Sma Negeri 22 Surabaya. Jurnal Mahasiswa Teknologi Pendidikan, 5(3).

Hartati, L. (2015). Pengaruh gaya belajar dan sikap siswa pada pelajaran matematika terhadap hasil belajar matematika. Formatif: Jurnal Ilmiah Pendidikan MIPA, 3(3).

Hardianti, F. (2019). Alat Permainan Edukatif Scrabble Untuk Meningkatkan Kemampuan Membaca Permulaan Anak Kelompok B. Jurnal Golden Age, 3(01), 17-29.

Hikmawanti, A., \& Sukanti, S. (2016). Penerapan Model Pembelajaran Kooperatif Teknik Teams Games Tournament (Tgt) Dengan Bantuan Media Scrabble Untuk Meningkatkan Keaktifan Belajar Akuntansi. Kajian Pendidikan Akuntansi Indonesia, 5(4).

Hikmawanti, A., \& Sukanti, S. (2016). Penerapan Model Pembelajaran Kooperatif Teknik Teams Games Tournament (Tgt) Dengan Bantuan Media Scrabble Untuk Meningkatkan Keaktifan Belajar Akuntansi. Kajian Pendidikan Akuntansi Indonesia, 5(4).

Kesumawati, N. (2008). Pemahaman Konsep Matematik dalam Pembelajaran Matematika. Semnas Matematika dan Pendidikan Matematika, 2, 231-234.

Larasati, F. A. (2017). Analisis Kelancaran Prosedural Siswa Sekolah Menengah Pertama Pada Materi Operasi Aljabar. e-Jurnal Mitra Pendidikan, 1(10), 995-1006.

Mardika, N. (2017). Pengaruh penggunaan scrabble Kata Terhadap Penyusunan Kalimat Bahasa Mandarin siswa kelas XI IPA2 SMA GIKI 2 Surabaya Tahun Ajaran 2017 2018. Mandarin Unesa, 2(02).

Putra, G. K. (2018). Pengaruh Penggunaan Media Permainan Scrabble Terhadap Daya Ingat Kosa Kata Bahasa Inggris Siswa Smp (Doctoral dissertation, Universitas Islam Negeri Sultan Syarif Kasim Riau). 
Priyanto, A. (2018). Peningkatan Kemampuan Pengenalan Sejarah Islam melalui Media Screabble Bagi Anak Usia Dini. KAGANGA: Jurnal Pendidikan Sejarah Dan Riset SosialHumaniora, 1(2), 72-81.

Ristanto, D. R., Sukardi, S., \& Susilaningsih, S. (2012). Peningkatan Perbendaharaan Kosakata Bahasa Jawa Melalui Media Permainan Scrabble. Joyful Learning Journal, 1(1).

Riawan, A., \& WANARTI RUSIMAMTO, P. U. P. U. T. (2018). Pengembangan Perangkat Pembelajaran Kooperatif tipe TGT (Teams Games Tournament) dengan Game Scrabble Pada Kelas XI TEDK Mata Pelajaran Penerapan Rangkaian Elektronika Daya dan Komunikasi di SMKN 5 Surabaya. Jurnal Pendidikan Teknik Elektro, 8(1).

Saadah, V. N., \& Hidayah, N. (2013). Pengaruh permainan scrabble terhadap peningkatan kemampuan membaca anak disleksia. Empathy, 1(1), 39-52.

Sugiyono, M. (2014). Metode Penelitian Kuantitatif dan R\&D.Bandung: Alfabet

Yualdi, N., \& Ganda Sumekar, T. (2013). Efektifitas Permainan Scrabble dalam Meningkatkan Kemampuan Membaca Permulaan bagi Anak Kesulitan Membaca. Jurnal Penelitian Pendidikan Khusus, 2(3).

Widiyarto, S. (2017). Pengaruh Penggunaan Media Permainan Scrabble Terhadap Keterampilan Menulis Teks Prosedur Siswa Kelas X, SMA Tugu Ibu, Depok, Jawa Barat. DEIKSIS, 9(03), 323-335. 